\title{
Mouldy Magenta - Celluloid to Digital: Giving a Second Life to Films
}

\section{Karen Chan}

https://doi.org/10.15664/fcj.v0i17.2064

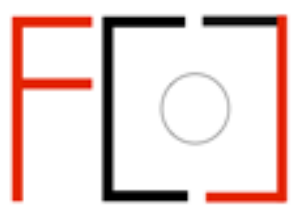

Frames Cinema Journal

ISSN 2053-8812

Issue 17 (Jun 2020)

(c)

http://www.framescinemajournal.com 


\section{Mouldy Magenta - Celluloid to Digital: Giving a Second Life to Films \\ Karen Chan (Executive Director, Asian Film Archive, Singapore)}

The year was 2006. A stack of rusty film cans wrapped in newspaper and plastic bags stood innocuously on the floor of the Asian Film Archive's (AFA) small office. A heavy sour scent filled the windowless space, intensifying as the minutes ticked by. The muscled pony-tailed gentleman with tinted glasses who had brought in the film cans wiped his brow as he told us a story that subsequently captivated audiences and excited film enthusiasts of Singaporean cinema.

The gentleman was Peter Chong, the lead actor of Singapore's only gongfu feature film, Ring of Fury (Tony Yeow, James Sebastian, 1973). His handshake was strong and decisive: 79 at the time of writing, Chong is still a practicing Kyokushin Karate Master, ranked $9^{\text {th }}$ Dan (the highest level is 10). Having starred in the 1973 film, he had been keeping the film cans at home for over thirty years. He was glad that he could finally deposit the $35 \mathrm{~mm}$ film reels with the AFA to look after. At this point Chong had no idea what to do with them and he was beginning to get worried about the condition of the film, as anyone who could smell the emissions coming from the cans instinctively knew it did not bode well. ${ }^{1}$

\section{Context and Significance}

Following the release of Bruce Lee's Fist of Fury (Lo Wei, 1972), the 1970s were marked by a gongfu craze. Ring of Fury was made in Singapore just a year later with a cast of non-professional actors as part of this wave. The film was co-directed and written by Singaporeans Tony Yeow and James Sebastian. ${ }^{2}$ Chong played the lead, a noodle seller turned pugilist who battled gangsters headed by a mysterious masked leader. It was a largely amateur production, in that parts of the film were unscripted and the fight scenes were not choreographed. According to Chong, the film was made on a shoe-string budget of SGD $\$ 80,000-100,000 .^{3}$ As such, there was no money for special effects, hence the prolonged fight scenes featured were raw and genuine fights between Chong and the other stunt members.

Upon completion, the film was banned for its portrayal of gangsterism, as this was a time when Singapore was aggressively "cleaning up" its public image. Films intended for exhibition or sale had to be submitted to Singapore's Board of Film Censors, which determined if the film could be exhibited or if scenes had to be cut in order for it to be screened publicly. Interviews of those who worked with the film censors in the 1970s indicated that censorship was extremely stringent toward any scenes that hinted at gangsterism. For instance, even the use of weapons like a flip knife or a knuckle duster were deleted since they were deemed to be related to gangsterism. ${ }^{4}$ As the entire premise of Ring of Fury was about gangsters and vigilantism it was therefore not allowed to be exhibited.

The ban was eventually lifted in the 1990s, with some sex and nude scenes cut. The film had a showing at Screen Singapore in 2005, a film festival held on the $40^{\text {th }}$ anniversary of the independence of Singapore. Audiences were struck by how magenta the film looked and even to the untrained eye it was obvious the film's condition was deteriorating severely. According to Chong only one print was struck since the film was banned, and he expressed regret that no one 
had ever thought to make a video copy; the surviving print had been submitted to the censors and the deleted scenes are lost. ${ }^{5}$ Thereafter, the film disappeared from the public eye.

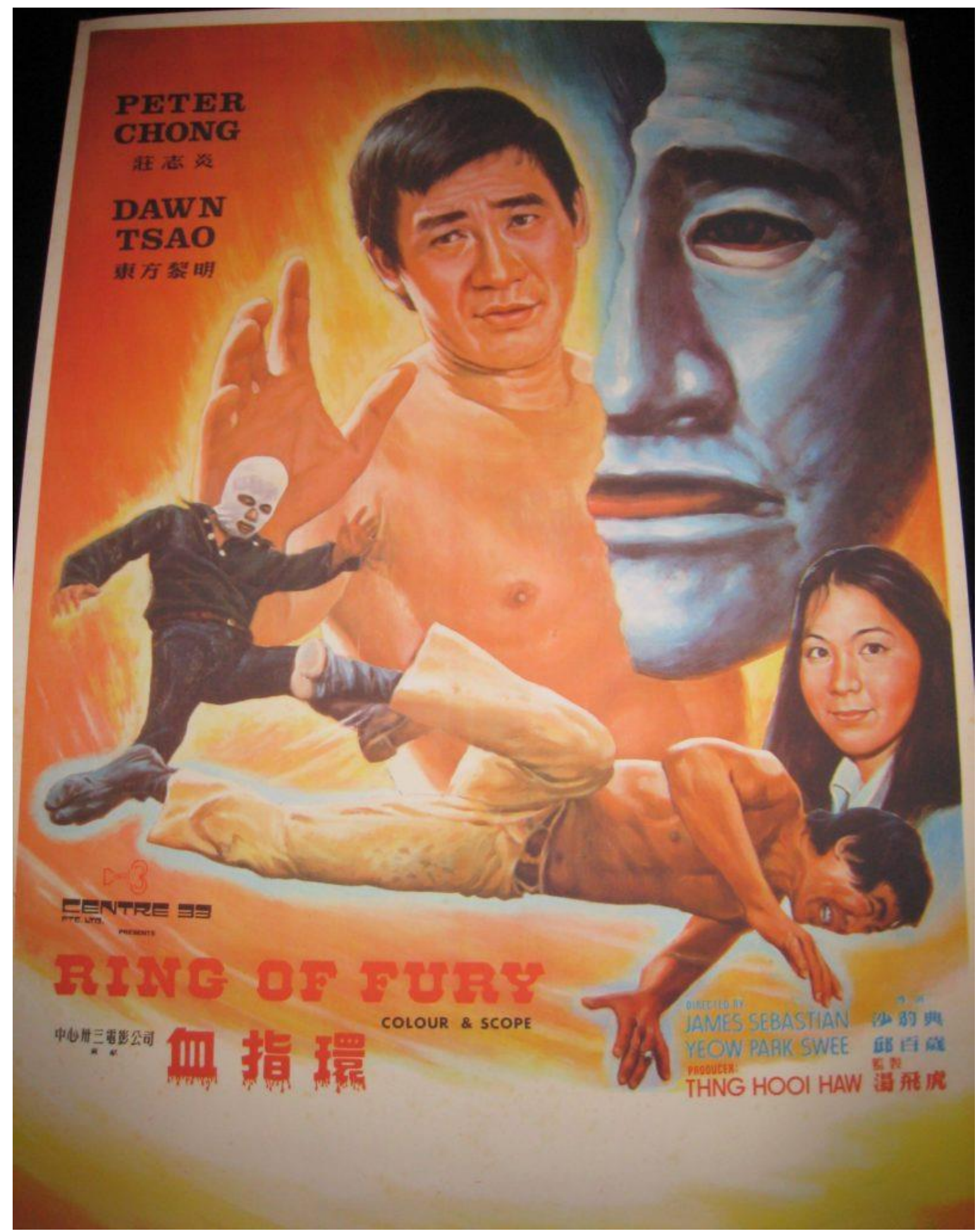

Figure 1: Original Ring of Fury poster, produced in 1973. Credit: Asian Film Archive

The history of Singaporean cinema is split into two - a post-war period and a revival period. The industry emerged from the beginning of the twentieth century, with the 1950s and 1960s, together, coming to be commonly referred to as the golden age of Singapore cinema. The films produced were largely in the Malay, Chinese dialect and Mandarin languages. Then, from the late 1970s to 
1991, Singapore's film industry came to a halt. In the 1970s, attempts at producing dubbed English-language films, featuring heavily accented American English, generally failed to replicate the earlier success of local productions. It is only after 1990 that the industry saw a revival, mainly with films predominantly in Mandarin and English, paralleling the domestic linguistic policies. ${ }^{6}$

Ring of Fury, like the other films made during the 1970s, was an early attempt to make a commercial genre film. The Singapore film industry might have gone in a very different trajectory had it not been banned.

Clichéd as it may be, things occurred for a reason. Chong found his calling in karate rather than acting, while Ring of Fury found its way to the AFA. Fast forward ten years to 2017. In 2016 the film had undergone an entire year of restoration and was ready to premiere at the annual showcase Asian Restored Classics (ARC). The annual ARC is a platform organised by the AFA for iconic Asian films that have been restored by different institutions to be appreciated by new audiences. More than 500 people who wanted to catch this rare film turned up for the screening of Fist of Fury. Since then, the restored version of Ring of Fury has not just been screened locally but also travelled to New York City, London, Beijing, Xiamen, and Kuala Lumpur.

The vastly improved clarity of the images that restoration had brought to the once magenta film enabled researchers to identify and verify new information and data on locations that are either no longer, have been transformed, or that are still there but may have been repurposed within the ever-changing Singapore landscape. For instance, the Satay Club at the Esplanade where Chong's character is seen selling noodles has been replaced by the domes of the Esplanade - Theatres on the Bay, and the main fight scene that takes place at the sand quarry at Tampines immortalises it. Thus, Ring of Fury serves as a moving documentation of the changing landscape. ${ }^{7}$

\section{Restoring the Film}

The restoration process is an extremely expensive one. It requires a great deal of expertise and is highly laborious. ${ }^{8}$ It is an endeavour that is embarked upon and reserved for priority film titles that are in most dire need. For the AFA, restoration is a means to an end. That end is to highlight the importance and urgency of preservation. If the original elements of a film are not preserved in the first place, then there will be nothing to restore from, and the film is lost forever. Where the budget permits, the AFA's policy continues to be to print restored films on celluloid film again for preservation, even with films now being digitally screened and accessed.

The 35mm print of Ring of Fury deposited by Chong was already in a much-deteriorated state, suffering from severe vinegar syndrome that had caused differential shrinkage. ${ }^{9}$ A build-up of mould and discolouration of faded yellow and cyan made all the print images appear magenta in colour. The poor condition of this sole surviving print of the film and its cinematic significance qualified it to be placed high on the priority list for restoration. Yet, it took the AFA almost a decade before there was sufficient funding to scan and restore the film in $4 \mathrm{~K}$ resolution.

The AFA adopts the principle that restoration is not simply about enhancing or improving the sound or image to make a film more beautiful. Rather it is about bringing the image and audio as close as possible to what the film would have looked and sounded like when it was originally 
projected. A major work component during the digital restoration was the removal of mould from the images and returning colour levels to close to their original state. The AFA team and the restorers struggled with the dilemma of just how much digital technology to apply towards the film in this respect. Eventually, the immense acidity and the high level of mould penetration across many of the picture frames led the team to decide that it was necessary to take a much more aggressive digital application to the restoration. This went against the usual practice of trying to use as little digital interference as possible during restoration, which is a paradoxical principle that archivists often tussle with restorers over. ${ }^{10}$

The restoration specialists at Cineric Portugal devoted numerous man-hours to meticulous manual cleaning. ${ }^{11}$ They developed a custom in-house software to detect and attenuate the mould in the blue and green channels. The faded colours and the presence of mould made the grading of the film particularly challenging. Colours had to be separated and saturated while maintaining natural skin tones. ${ }^{12}$ As there were no other film elements or related materials such as photographs/stills to enable comparisons, the restoration team had to make their best calculated judgements. Chong, as the only available locally based cast/crew member of the film, was also invited to watch a preview of the film and provide his comments. 


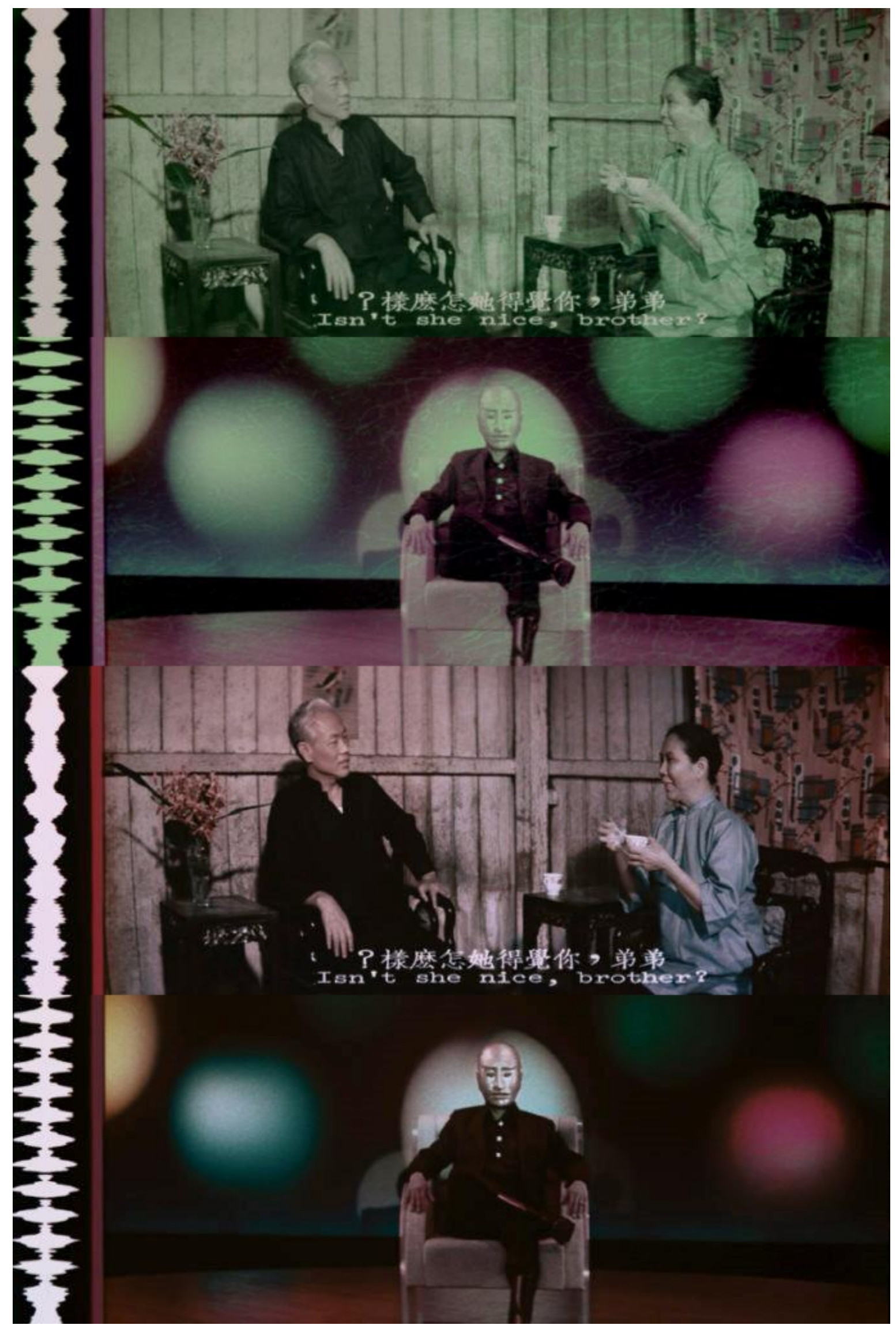

Figure 2: Before and after the restoration of Ring of Fury, illustrating the discolouration and green mouldy streak. Credit: Asian Film Archive 
Besides image and audio restoration and grading, subtitling is another important aspect of restoration work. The rule of thumb with older Asian films is to use the native Asian language of the producing country. The AFA translates the film and creates new English language subtitles that accompany the restored version to make the films accessible to a wider audience. In the case of the sole surviving original print of Ring of Fury, we found the presence of both English and Mandarin subtitles that had been burnt-in on the film. Without a clean film copy to work from, there was little choice but to leave the existing subtitles intact on the restored film, since removing them with current technology would be immensely costly. The old subtitles give the restored film a unique flavour that allows future audiences to be exposed to the original language of the 1970s.

\section{Collaborative Archiving}

The AFA's efforts at priority restorations for titles that are in the worst condition have led to it working with different archival institutions around the world. The case of Ring of Fury, which had never been shown as it was banned immediately upon completion, was one of a kind. We could confidently conclude that apart from the print deposited to us, no other film elements would be residing in any archive.

However, for another film that we initially thought lost but knew had screened in multiple countries, namely They Call Her... Cleopatra Wong (George Richardson, 1978), there was hope that a copy might be sitting somewhere in the world. In 2012, Marrie Lee, the lead actress of the film, and the AFA joined forces to started searching. This included making calls to member institutions of the International Federation of Film Archives (FIAF) and of the Southeast Asia Pacific Audiovisual Archives Association (SEAPAVAA). The effort paid off as some years later we located a $35 \mathrm{~mm}$ German-dubbed release print at the Filmarchiv Austria as well as a $16 \mathrm{~mm}$ release print with burned-in Danish subtitles at the Danish Film Institute. This news was ecstatically received akin to the level of excitement of that of having discovered gold. The AFA was able to restore the film as a result of the assistance from these two archives. The long-awaited restored version of They Call Her... Cleopatra Wong will finally be making its premiere in Singapore in 2020.

This success story illustrates once again the crucial point that without preservation it would not be possible to restore films for a new generation. The practice of film preservation in Austria and Denmark showed its best side in this transnational collaboration. If a country's cinematic heritage is to have any chance of surviving, preservation must be supported by both private and public sectors, by all stakeholders, users and the community. 


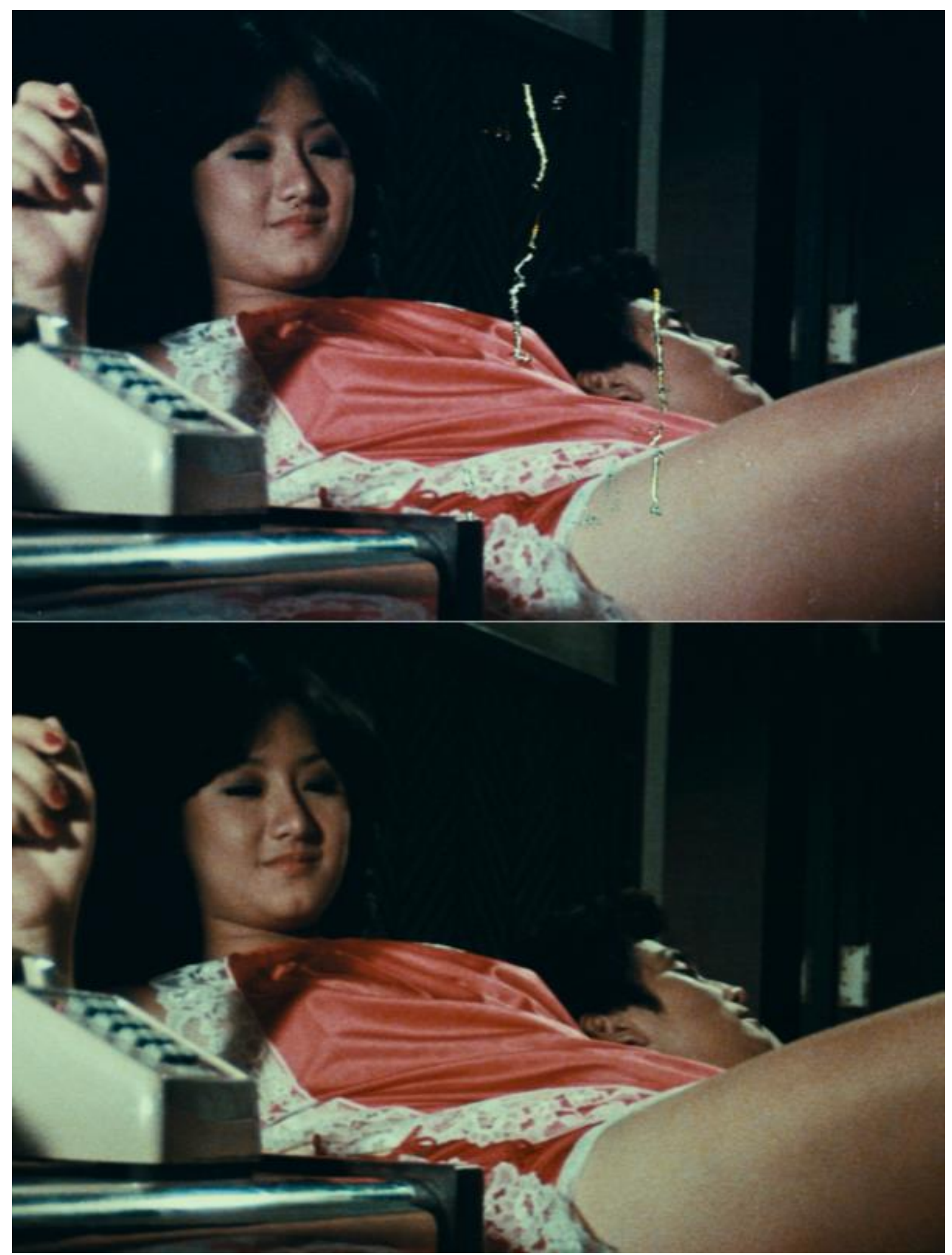

Figure 3: Before and after the restoration of They Call Her... Cleopatra Wong. Credit: Asian Film Archive

Over the last few years, the AFA has collaborated with a variety of partners to restore at risk Asian film titles. These partnerships provide the best opportunity for more films to be made available once again for screening and for research. An example of this was AFA and the Memory International Film Festival working together in 2017 to restore My Darling (Pyo Chit Lin, U Tin 
Myint, 1950). The silent film was Myanmar's earliest surviving classic on colour film, that starred many of the major Burmese actors of the time. A music score for the film was commissioned and performed by traditional Myanmar musicians.

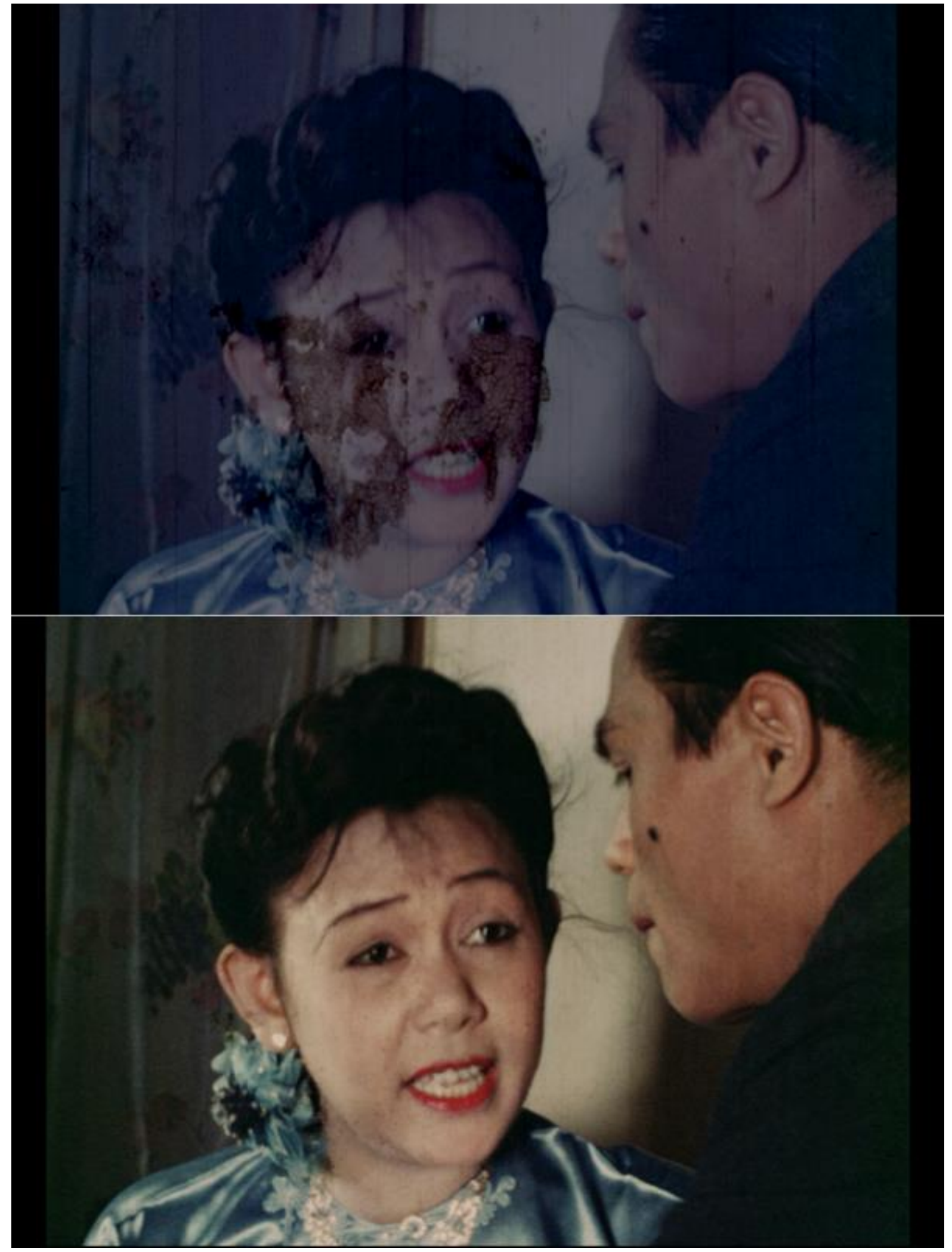

Figure 4: Before and after the restoration of Pyo Chit Lin. Credit: Asian Film Archive 
Institutions such as the Hong Kong Film Archive, Taiwan Film Institute, the Japan Foundation, the National Film Archive of Japan, Sinematek Indonesia and the British Film Institute have all worked with the AFA to assist in making a restoration possible. Whether loaning film copies, photographs or dialogue scripts, the willingness to share information is instrumental in enabling every archive's endeavour to preserve a slice of their film culture.

Films have a special place in society to nourish souls. Borrowing the eloquence of this quote from Phil Daoust on the remarkableness of trees, it can be argued too that films can similarly "inspire awe and affection, comfort us in times of trouble, are landmarks in our journeys through the landscape and life itself'. ${ }^{13}$

At the time of writing this article the world is grappling with a global health pandemic. The film archiving community is affected due to some planned conferences being cancelled, events being moved online, and audiences choosing to stay home instead of heading to a cinema. Under these troubling and confusing circumstances, the work of archives continues as archivists prepare the cinematic treasures of the past to be ready for present and future audiences to nourish all souls.

\footnotetext{
1 The AFA was founded in 2005. Peter Chong came to us with his film in 2006. He had been encouraged by Philip Cheah, one of Singapore's respected film programmers, to look up the AFA so that his film reels could be preserved, especially since it was obvious from a 2005 screening that the film was not in good shape.
}

2 Tony Yeow $(1938$ - 2015) started his career in the 1960s as a television and radio producer of commercials, documentaries, and campaign films for the Singapore government. He went on to dabble in acting, directing and producing film projects. James Sebastian $(1933-)$ supervised a team of television cameramen and film editors before becoming a scriptwriter for the next thirty years. He migrated to Australia in 1984 and continues to live there with his family.

${ }^{3}$ Boon Chan, "Singapore's first gongfu flick, Ring of Fury, in Asian Restored Classics", The Straits Times, 25 Aug 2007. Available: https://www.straitstimes.com/lifestyle/entertainment/total-knockout (Accessed 15 March 2020)

${ }^{4}$ Rama Meyyappan, “Celebrating Our Pioneers”, Singapore Memory Project, 2005. Available: https://www.singaporememory.sg/contents/SMA-9943a80b-8db5-46fc-87e2-971294514502 (Accessed 20 March 2020)

${ }^{5}$ Chan, The Straits Times, 25 Aug 2007.

${ }^{6}$ Kent Chan, "The Has-Been That Never Was: A profile of maverick producer-director Tony Yeow”, Cinémathèque Quarterly, Vol. 1: January-March 2017, p. 38.

7 Zhaki Abdullah, "Places lost and found in Singapore movies", The Straits Times, 31 August 2017. Available: https://www.straitstimes.com/singapore/places-lost-and-found-in-spore-movies (Accessed 15 March 2020)

${ }^{8}$ Depending on the condition of the elements, the number of man-hours, and the range of expertise required, restoration projects that AFA has embarked upon have ranged between USD\$80,000 - USD\$150,000.

\footnotetext{
${ }^{9}$ Vinegar syndrome is a chemical reaction of the acetate ion from the cellulose triacetate of film reels reacting with moisture to form acetic acid, thus producing the vinegar-like smell. Once the condition has set in, the reaction cannot be stopped or reversed. It feeds on itself and will accelerate over time. In colour films, the acid causes dye fading and damage to both the image and the base. Cold storage is the recommended way to control further deterioration.
}

${ }^{10}$ Fumiko Tsuneishi, "From a Wooden Box to Digital Film Restoration”, Journal of Film Preservation, Issue 85, Oct 2011, p.72. 
${ }^{11}$ A major criteria when deciding which laboratory was to oversee the restoration of Ring of Fury, aside from price competitiveness, was the need for confidence when handing fragile and deteriorating film elements to the restorer. Cineric Portugal is a collaboration between Cineric Inc., based in New York, and the Cinemateca Portuguesa (Portugal Film Archive), based in Lisbon. The Portuguese archive staff oversee inspection and repair of film material, so it was reassuring to know that Ring of Fury would be well taken care of. Knowing how badly the mould had infected the print, the assurance that Cineric's director of technical operations was personally overseeing the project was particularly important. In addition, Imagica Lab in Japan is probably the most experienced in Asia, with a fully equipped and dedicated restoration arm. There are other labs in Taiwan, Thailand, and the Philippines, but these are mostly post-production companies that take on aspects of digital restoration.

${ }^{12}$ Notes on the restoration of the film by Cineric Portugal. Available: https://www.cineric.pt/films/ (Accessed 15 March 2020)

13 Phil Daoust, "Special branches: Readers on the trees that changed their lives" The Guardian, 4 March 2020. Available: https://www.theguardian.com/lifeandstyle/2020/mar/04/special-branches-readers-on-the-trees-thatchanged-their-lives (Accessed 15 March 2020)

\begin{abstract}
About the Author
Karen Chan is the Executive Director of the Asian Film Archive (AFA). She joined the AFA in 2005 and now oversees its development, from preservation and restoration, to the curation of programmes and publications. She advocates for and runs classes on film literacy and preservation for educators and students. Karen contributes to archiving and library publications and has jointly written a chapter on "Independent digital filmmaking in Singapore" for the book Singapore Cinema. She regularly presents at conferences, most recently at the 2019 Heritage Conservation Centre International Conference, the 2019 International Film Restoration Forum in Xiamen University, Tokyo International Film Festival's CROSSCUT ASIA 2019, and the 2018 EYE International Conference, Amsterdam. Karen served on the Executive Council of the Southeast Asia-Pacific Audiovisual Archives Association and is part of the Advisory Committee of the Singapore Film Commission. She was previously a teacher, and has worked at the National Archives of Singapore, the National Arts Council and the Natural History Museum in New York City.
\end{abstract}

